\title{
Introduction
}

\section{A Possible Strangeness: Reading Russian Science Fiction on the Page and the Screen}

\section{ANINDITA BANERJEE}

\begin{abstract}
"A man is half of what he is, and half of what he wants to be," said Oscar Wilde. If that is the case, then Soviet children of the sixties and seventies were all half cosmonauts. ... The cosmos was everywhere, in school textbooks, on the walls of houses, on the mosaics in the Moscow metro. ... Under the window of every five-story Khrushchev apartment stood miniature models of satellites. On the tear-off wall calendars, one spaceship followed another.
\end{abstract}

\begin{abstract}
$\mathrm{Y}$ ou could say that it all started with Sputnik. Sputnik, meaning "companion" in Russian, was the first artificial satellite to break free of the atmosphere and orbit the earth on October 4, 1957, almost a hundred years after Jules Verne wrote First Men on the Moon in 1865 and just one month ahead of the fortieth anniversary of the great utopian experiment of the October Revolution. Sputnik embodied a long-anticipated convergence of science fiction with science fact that reverberated across a planet still recovering from the ravages of
\end{abstract}

1 Victor Pelevin, “Code of the World," trans. Kirill Zikanov, Frankfurter Allgemeine Zeitung, February 28, 2001, accessed April 1, 2017, http://www.knigo.com/p/PELEWIN/code_world_engl.htm. 
the Second World War, and, in the case of the Soviet Union, from three decades of domestic repression that had recently ended with the death of Josef Stalin in 1953. Though still locked in a Cold War with its geopolitical rival across the Atlantic, the country was entering an era of political, economic, and cultural liberalization at home, with calls for "coexistence" in the international arena under the new leader Nikita Khrushchev-a brief period called the Thaw that was named after a novel by Ilya Ehrenburg, a renowned public intellectual who had himself experimented with writing science fiction after the 1917 revolution.

The ridiculously small sphere orbiting the earth in 1957, twice the size of a soccer ball and weighing only eighty-four kilograms, carried an outsized symbolic weight. It ushered in a whole new way of imagining the self in relation to other worlds far beyond the geographical boundaries and historical travails of our imperfect planet. It embodied a dream cultivated by science fiction writers and technological visionaries that had remained tantalizingly out of humanity's grasp. Most significantly, Sputnik brought everyday life into exhilaratingly close proximity with vast scales of space and time. Part of its appeal was its own accessibility: the satellite could be seen with the naked eye at dawn or dusk from anywhere on the earth's surface, and emitted a chirping signal that could be captured on any short-wave radio. Its launch was the first of many "space firsts" that captivated the world's imagination over the next decade. They included sending the first life form, the legendary dog Laika, on Sputnik II a mere month later; the successful return journey of the canine twins Belka and Strelka in 1960; Yuri Gagarin's first manned mission in 1961; and the flight of Valentina Tereshkova, the first woman in space, in 1963. Until the United States caught up with its own iconic moon landing in 1969, the Soviet Union drew the world into a thrilling participatory spectacle of future-thinking and future-making unfolding in real time.

Each breakthrough was broadcast live on radio and television, providing endless fodder for anticipation and speculation to commentators who adopted a distinctly science fictional tone. Newspapers and burgeoning popular science journals such as Around the World (Vokrug sveta), Knowledge is Power (Znanie-Sila), and the Technology for youth (Tekhnika-molodezhi), newly galvanized by the unfolding drama in outer space, vied for the pleasure of taking every reader along for a ride into the unfathomable. ${ }^{2}$ As the contemporary writer and science fiction

2 For an overview of science fiction in periodical culture of the early Space Age, see Matthias Schwartz, Die Erfindung des Kosmos. Zur sowjetischen Science Fiction und populärwissenschaftlichen Publizistik vom Sputnikflug bis zum Ende der Tauwetterzeit [The discovery of the cosmos: On Soviet science fiction and popular science periodicals from the Sputnik launch to the end of the Thaw] (Frankfurt, 2003). 
$\mathbf{x} \mid$ Introduction

enthusiast Victor Pelevin so eloquently recalls, the cosmos-as outer space was called in Russian - literally came home through objects and narratives woven into daily commutes and evening playtimes, public art and domestic knickknacks. The infinite universe had become thoroughly intimate, generating its own economy of desire by virtue of its ubiquitous presence in the places and practices of everyday life. Saturating the material, intellectual, and imaginative worlds of both adults and children, the cosmos, like science fiction itself in Fredric Jameson's famous formulation, had reached out and colonized reality. ${ }^{3}$

In the wake of Sputnik, Russia could also make a special historical claim to the condition that Pelevin describes as a foot in the real world and a foot in the cosmos - a mode of being, thinking, and acting that Istvan CsicseryRonay has called "the science fictionality of everyday life." ${ }^{4}$ Soon after Gagarin's flight, Khrushchev posthumously feted an obscure figure from the early twentieth century on the Red Square. Broadcast with much fanfare on national television and extensively written up in the press, the ceremony transformed Konstantin Tsiolkovsky, a rural teacher of mathematics who first popularized the term "cosmos" in the early 1900s, into the universally beloved grandfather of the Soviet Space Program. Tsiolkovsky stood out among his contemporary visionaries who, like their European and North American counterparts, were obsessed with the prospect of interplanetary communications and space travel. The biologist Alexander Bogdanov, for instance, in his novel Red Star (Krasnaia zvezda), imagined a Bolshevik utopia on Mars as early as 1908. The filmmaker Iakov Protazanov visualized a Soviet scientist landing on the red planet in Aelita, one of the earliest full-length science fiction films, in 1924. Tsiolkovsky's prolific body of science fiction, however, served a further purpose: unlike the purely speculative conjectures of his contemporaries, it communicated the fundamentals of aerospace engineering to its audience. The mathematician wove prescient designs for jet-propulsion engines and gravity-free interiors into fantastical tales of space travel penned between 1895 and the 1920s.

Tsiolkovsky's apotheosis also signaled the triumphant return of science fiction to Soviet life after nearly three decades of being marginalized from mainstream culture. ${ }^{5}$ It had been driven underground in the early 1930 s

3 Fredric Jameson, "Progress versus Utopia; Or, Can We Imagine the Future?" Science Fiction Studies 9, no. 27 (1982): 149.

4 Istvan Csicsery-Ronay, The Seven Beauties of Science Fiction (Middletown, CT: Wesleyan University Press, 2008), 2.

5 On the media coverage of Tsiolkovsky's public recognition and its impact on the relegitimization of science fiction, see Anindita Banerjee, "Between Sputnik and Gagarin: Space 
when socialist realism came to be officially endorsed by the state as the only viable kind of art for a revolutionary society; according to an apocryphal but frequently cited account, Stalin himself had forbidden speculation beyond the realistic horizons of the near future. ${ }^{6}$ Under the twin signs of the Space Age and the Thaw, however, enthusiasts of the cosmos began to rediscover and reclaim an earlier golden era of nauchnaia fantastika or "scientific fantasy." The Russian term for science fiction, which had first emerged in the 1890s and become increasingly popular in the period leading up to the October Revolution, once again began to appear on the pages of magazines, the cover of books, and in titles and credits on the big screen. ${ }^{7}$ In 1962, a journal called Fantastika was launched for catering to aficionados of the genre, which reprinted works from the revolutionary era alongside contemporary publications. The same year, a lavish new film returned to Alexander Beliaev's bestselling novel from 1928, The Amphibian Man (Chelovek-amfibii), for plunging its Space Age audience into another unfathomable, little-explored dimension: the depths of the ocean. ${ }^{8}$

The science fictionality of everyday life that Pelevin associates with his childhood no doubt primed readers and moviegoers for a veritable flood of novels, stories, and films that continue to be venerated as exemplars of the genre to this day. They included The Andromeda Nebula (Tumannost' Andromedy), Ivan Efremov's saga about intergalactic socialism published almost simultaneously with the Sputnik launch in 1957; the prolific fiction of the brothers Arkady and Boris Strugatsky, whose work through the 1960s and '70s deeply engaged with the mysteries of cutting-edge technological developments yet was palpably critical of their social and political uses; and Andrei Tarkovsky's cinematic masterpieces Solaris (1972), lauded as a response to Stanley Kubrick's 2001: A Space Odyssey (1968), and his later film Stalker (1979), set in an ambiguously alien wasteland adapted from the Strugatskys' novel The Roadside Picnic. Science fiction, moreover, provided a potent platform for reaching out to the world, not just among the Soviet Union's allies

Flight, Children's Periodicals, and the Circle of Imagination," Children's Literature in Soviet and Post-Soviet Russia, ed. Marina Balina and Larissa Rudova (New York: Routledge, 2008), 74-75.

6 Matthias Schwartz, "How Nauchnaia Fantastika was Made: The Debates about the Genre of Science Fiction from the NEP to High Stalinism," Slavic Review 72, no. 2 (2013): 224-46.

7 Anindita Banerjee, We Modern People: Science Fiction and the Making of Russian Modernity (Middletown, CT: Wesleyan University Press, 2013), 1-9.

8 Chelovek-Amfibii [The human amphibian], dir. Vladimir Chebotarev, Leningrad, 1962. 
xii | Introduction

in the Eastern Bloc but also farther afield in the West and among the newly decolonized nations of Latin America, Asia, and Africa. Progress Publishers of Moscow released a selection of Tsiolkovsky's essays, notes, and interviews in English in 1970. 9 Tarkovsky's mystifying films won multiple awards at Cannes and elicited much commentary from Kubrick fans worldwide. Throughout the sixties and the seventies, Progress translated contemporary authors as well as selected early-twentieth-century luminaries of science fiction for distribution in many languages and regions.

Sputnik's impact-crossing the boundaries of private life and public culture, domestic enthusiasm and international curiosity, technological spectacle and participatory entertainment, contemporary aspirations and historical visions, and, last but not least, the diverse media of print, film, radio, and television-played an instrumental role in transforming science fiction from Russia into a serious object of study. The opening essay of this reader, arguably the first work on Russian science fiction published in English with an extensive bibliography, was penned in 1971 during the peak of the space fever on both sides of the Cold War. Its author, the Croatian-born literary theorist Darko Suvin, advanced the first theory of the genre in his 1979 book Metamorphoses of Science Fiction and became a founding figure of the field of science fiction studies worldwide. ${ }^{10}$ With the tantalizing phrase "a possible strangeness," Suvin's contribution sets the stage for understanding why Russian science fiction continued to attract an ever-widening field of scholars and critics over the subsequent decades, even and especially after the Space Age lost its heady fervor and the Soviet Union itself ceased to exist in 1991. The contents and organization of this critical reader reflect the ways in which the Space Age provided both the momentum and the template, much as it had done with the figure of Tsiolkovsky himself, for critics to simultaneously reach backward and forward in time. ${ }^{11}$ Their endeavors recover a surprisingly long history of the genre in Russian literature and cinema, in the process revealing a dizzyingly diverse array of formal innovations and thematic preoccupations.

Research on the topic took on a new urgency in the 1980s, when it first became clear that the almost century-long living experiment of creating a

9 Konstain Tsiolkovsky, The Call of the Cosmos, trans. V. Danko (Moscow, 1970).

10 Darko Suvin, Metamorphoses of Science Fiction: On the Poetics and History of a Literary Genre (New Haven, CT: Yale University Press, 1979).

11 The first historical study of nauchnaia fantastika in Russian, published five years after Suvin's seminal essay, was A. N. Britikov's Russkii-sovetskii nauchno-fantasticheskii roman [Russian and Soviet science fiction novels] (Moscow, 1976). 
utopian alternative to Western industrial capitalism was coming to a close. ${ }^{12}$ Under the banner of perestroika and glasnost, several key authors and works that had been suppressed or merely retreated into oblivion were resurrected, reissued, translated, and studied for the first time within and beyond Russia's borders. Bogdanov's Red Star, which after its initial success fell into disfavor among Bolsheviks at least in part because of V. I. Lenin's condemnation of its "mystical tendencies," and Protazanov's Aelita, which was commercially successful but ideologically suspect in the eyes of the new Soviet commissars, attracted renewed attention from critics and translators. Among other rediscovered early classics were Mikhail Bulgakov's short story The Fatal Eggs (Rokovye iaitsa) and the novel Heart of a Dog (Sobach'e serdtse): of these satires about the grand experiment of forging a New Soviet Man in Russia's roaring twenties, the first was published in 1925, while the second appeared in print only in 1987. A similarly uneven publication history lay behind the return to print of the highly experimental early science fiction of Andrei Platonov, a hydrologist and engineer who participated in the Bolshevik project of transforming a largely agrarian country into a technological trailblazer. Evgenii Zamiatin's We $(M y)$, a dystopian novel written in 1921, did not appear in its original language until the late 1980s despite, or perhaps because of, having inspired George Orwell's 1984. This work is perhaps the most famous example of a sciencefiction text that has been mined endlessly for a key not just to Russia's turbulent relationship with the twentieth century, but to the modern human condition as a whole.

Critical readings of Russian science fiction have continued to grow exponentially since then, and not just within the traditional disciplinary boundaries of literary and cinema studies. The essays collected in this volume confirm what became palpably evident in the Sputnik era: a genre that is perpetually poised, like Pelevin's child-cosmonaut, at the threshold between what is and what could be is not a product of the writer's study or a filmmaker's studio

12 Among the foundational studies emerging from this period are Leonid Heller, De la Sciencefiction soviétique: Par delà le dogme [Soviet science fiction: Some thoughts on ideology] (Lausanne, 1979); John Griffiths, Three Tomorrows: American, British, and Russian Science Fiction (London: Macmillan, 1980); and Patrick McGuire, Red Star: Political Aspects of Soviet Science Fiction (Ann Arbor, MI: UMI Research Institute, 1985). 1989 and the fall of the Berlin Wall saw another wave of scholarly interest, exemplified by Richard Stites's Revolutionary Dreams: Utopian Visions and Experimental Life in the Russian Revolution (Oxford: Oxford University Press, 1989) and Yvonne Howell's Apocalyptic Realism: The Strugatsky Brothers' Science Fiction (Middlebury, VT: Russian and East European Studies inthe Aesthetics and Philosophy of Culture, 1994). 
alone. From the period when nauchnaia fantastika first emerged as a vibrant label at the turn of the twentieth century through its current metamorphoses after the demise of the Soviet Union's governing ideology of scientific materialism, science fiction in Russia has been cocreated and coproduced by an astonishingly large community that included scientists and engineers, philosophers and policymakers, social and political activists, journalists, artists, illustrators, and, above all, consumers, with their frequently flawed material lives and often unfulfilled aspirations. In Russia perhaps more than anywhere else, science fiction served as the battleground for competing attitudes toward not just science and technology but the very idea of their role as the engines of modernityan endlessly generative and constantly mutating crucible for what Raymond Williams termed "structures of feeling."13

In keeping with the disjunctive processes through which science fiction served not so much as a mirror of history or culture as a laboratory of simultaneously thinking, doing, and becoming, the articles in this critical reader expose the genre as inherently transnational, inter-generic, transmedial, and transhistorical. This was as true of what Zamiatin called the art of "displacement, distortion, curvature, [and] nonobjectivity" inspired by the scientific and technological revolutions of Einstein's relativity, aviation, the radio, telegraph, and cinema at the turn of the twentieth century as it was of subsequent radical experiments in transforming bodies, minds, and the physical environment. ${ }^{14}$ Following the cautionary dictum of Suvin himself in his later writings about science fiction, the chapters following this introduction refuse to stay within narrow analytical frameworks of purely artistic influences, established literary or cinematic canons, hermetic compartments of historical periods, and monolithic conceptions of ideology flowing unilaterally from

13 Raymond Williams, "Structures of Feeling," in Marxism and Literature (Oxford: Oxford University Press, 1977), 128-35. Andrew Milner, in his recent book, Locating Science Fiction, has similarly defined the genre as a "site of contestation" between incommensurable attitudes, registers, and forms of culture (Liverpool: Liverpool University Press, 2012), 39-40.

14 Yevgeny Zamyatin, "Literature, Revolution, Entropy and Other Matters," in A Soviet Heretic: Essays by Yevgeny Zamyatin, trans. Mirra Ginsburg (Chicago: University of Chicago Press, 1970), 112. For intricate histories of science fictional thinking in actual research, development, and policy, see Loren Graham's The Ghost of the Executed Engineer: Technology and the Fall of the Soviet Union (Cambridge, MA: Harvard University Press, 1996); and Nikolai Krementsov's A Martian Stranded on Earth: Alexander Bogdanov, Blood Transfusion, and Proletarian Science (Chicago: The Univesity of Chicago Press, 2011) and Revolutionary Experiments: The Quest for Immortality in Bolshevik Science and Fiction (Oxford: Oxford University Press, 2013). 
the state. ${ }^{15}$ Instead, they trace the complex "intra- and inter-generic dialogues" identified by Gary Saul Morson through a great diversity of forms and platforms, extending through and flowing between intellectual, ideological, material, and media cultures over the long arc of the twentieth century and beyond. ${ }^{16}$ The articles highlight the treasure trove of material that Russian science fiction has provided not only to literary and media studies, but also to intellectual and cultural history and interdisciplinary studies of science and technology.

The four sections of this reader are arranged in a broad chronological order that corresponds with major shifts in Russian history and culture on the one hand and the emergence of science fiction in print and in moving pictures on the other. Such boundaries are hard to enforce, however, and not just because of the uneven history of reception and scholarship as outlined above. Literary and cinematic works of science fiction, perpetually looking beyond the horizons of the here and now, inherently leak through and spill over periods, movements and indeed their own conventions. As a way of accommodating this heterogeneity, this reader strives to balance the perspectives of the telescope and the microscope, interspersing articles that provide rich overviews of particularly instrumental times and themes with those that provide nuanced analyses of authors, directors, and works that are most likely to be encountered in the classroom and revisited for pleasure.

The first section, "From Utopian Traditions to Revolutionary Dreams," begins with Suvin's pioneering essay, followed by Mark Adams's examination of the remarkable life and times of the author of Red Star. The next chapter presents an extended inquiry into a question often left implicit in science fiction's fantastical projections of technology, but which in Russia's case became a governing obsession from the eighteenth century all the way to the October Revolution and beyond: how to power the future in both the material and the ideological senses. In the last chapter of this section, Asif Siddiqi similarly traces a thriving prehistory of the popular culture of spaceflight, ranging widely between Tsiolkovsky's visionary writings and amateur clubs of rocket-builders, between mixed-media art exhibitions and early spectacles of photography and cinema.

The next section, "Russia's Roaring Twenties," focuses on the decade immediately following the October Revolution that produced some of the most famous and most controversial science fiction. Following Dominic Esler's

15 Darko Suvin, "Narrative Logic, Ideological Domination, and the Range of SF," Positions and Presuppositions in Science Fiction (Kent, OH: Kent State University Press, 1988), 64-66.

16 Gary Saul Morson, The Boundaries of Genre: Dostoevsky's Diary of a Writer and the Traditions of Literary Utopia (Austin, TX: University of Texas Press, 1981), 79. 
xvi $\mid$ Introduction

overview of the incendiary mix of hope, anxiety, and fear that set science fiction apart in this era, three chapters by leading scholars and critics provide in-depth analyses of some of the most abiding early classics of Russian science fiction. Eliot Borenstein looks at language in Zamiatin's We as an ideological battleground between collective conformity and the rebellious self. Interpreting Protazanov's Aelita as an allegory of Russia's "domestic drama" of economic and social transition, Andrew Horton in the next essay offers a revisionist reading of its techniques and spectatorship. Working at the interface between science fiction and the institutional history of the biomedical sciences, the last chapter of this section by Yvonne Howell locates Bulgakov's monstrous hybrids in the almost equally fantastical culture of Bolshevik eugenics.

The third section of the reader, "From Stalin to Sputnik and Beyond," similarly places the breakthrough science fiction of the Space Age in the cloud chamber of a longue durée - a challenge to the view that the utopian aspirations of earlier decades had gone into complete hibernation during the Stalin years. To be sure, there is little science fiction in literary form to show for the period between the early 1930s and the late 1950s. The first two chapters of this section, however, demonstrate that the dream factory of the revolutionary era was kept alive through the wondrous medium of cinema. An excerpt from Michael G. Smith's recent study, Rockets and Revolution, illuminates the transnational traffic in multiple media that continued to build upon earlier science fictional projections of spaceflight, culminating in a little-known but remarkable episode of "Stalinist cosmonautics": Vasily Zhuravlev's 1936 film, Cosmic Voyage, whose stunning simulations of zero-gravity environments were supervised by none other than Tsiolkovsky. The recently unearthed chronicles of innovative space cinema continues in the next chapter, based on interviews and archival materials obtained from Pavel Klushantsev by Lynn Barker and Robert Skotak. Klushantsev, whose work is only now getting the critical attention it deserves, made documentaries as well as fiction films depicting the cosmos at the dawn of the Space Age; footage from his 1961 film Planet of the Storms was sold off to Hollywood, appearing years later in Peter Bogdanovich's 1968 directorial venture, Voyage to the Planet of Prehistoric Women. ${ }^{17}$ The last two chapters of this section tackle the two greatest icons of science fiction literature and cinema

17 On Klushantsev's innovations, see Birgit Beumers, "Special/Spatial Effects in Soviet Cinema," Russian Aviation, Spaceflight, and Visual Culture, ed. Vlad Strukov and Helena Goscilo (London: Routledge, 2016), 169-88. 
from the Space Age. Csicsery-Ronay's landmark essay investigates the irrepressible paradigms of folklore and fairy tales in the Strugatsky brothers' formidable corpus of work. Andrei Tarkovsky's two forays into science fiction cinema, Solaris and Stalker, constitute the subject of Christopher Dalton's commentary on the interpenetration between inner and outer space.

The final section of this reader, titled "Futures at the End of Utopia," attempts to map out the nebulous contours of science fiction in the era when writers such as Pelevin look back with both disillusionment and nostalgia at the dreams of futures past. In order to investigate Pelevin's own playful engagement with the present, Elana Gomel turns to postmodernism, which the cultural theorist Mark Lipovetsky has defined as a dominant condition of contemporary life and art. ${ }^{18}$ Investigating the kind of fantasy that has replaced the hard science fiction of the sixties and seventies, Vlad Strukov examines Timur Bekmambetov's blockbuster vampire movies, Night Watch and Day Watch, through the lens of intergenerational disjunction and dysfunction. The critical reader closes with a sweeping view of anti-realist fiction in the 2000s that Aleksandr Chantsev trenchantly calls the "Dystopia Factory."

Even now, a hundred years after the Revolution, sixty years after Sputnik, and more than a quarter century after the demise of the USSR, first encounters with Russian science fiction may come as something of a shock to students, scholars, and fans alike, no matter how well-versed they might be in the massive Anglo-American tradition of literary science fiction or how steeped in its Hollywood-driven cinematic forms. Far from curbing their cognitive wonder, to use another felicitous phrase from Suvin's opening essay, this critical reader hopes to catapult them into further realms of its possible strangeness.

18 Mark Lipovetsky, Russian Postmodernist Fiction: Dialogue with Chaos, trans. and ed. Eliot Borenstein (London: M. E. Sharpe, 1999). 
